\title{
Coronary ectasia: manifesting as acute coronary syndrome
}

\author{
Himanshu Mahla, Anshu Kabra, Shivakumar Bhairappa, Rangaraj Ramalingam
}

Department of Cardiology, Sri Jayadeva Institute of Cardiovascular Sciences \& Research, Bengaluru, Karnataka, India

\section{Correspondence to} Dr Shivakumar Bhairappa, snbhairappa@gmail.com

\footnotetext{
To cite: Mahla H, Kabra A, Bhairappa S, et al. BMJ Case Rep Published online: [please include Day Month Year] doi:10.1136/bcr-2013010153
}

\section{DESCRIPTION}

A 56-year-old woman presented with 2 days history of anginal chest pain. No risk factors for coronary artery disease, except family history in paternal uncle. Cardiac examination was normal. ECG showed ST segment depression in leads V1-V6. Echocardiography showed regional wall motion abnormality in left anterior descending artery (LAD) territory with adequate left ventricle ejection fraction. The patient's troponin $T$ test was positive according to reference laboratory standards. The patient was diagnosed as having acute coronary syndrome-non-ST segment elevation myocardial infarction.

Coronary angiogram showed triple vessel disease-ectatic coronaries. Proximal LAD was ectatic with occlusion at proximal -mid junction (figure 1, video 1). Left circumflex coronary artery was non-dominant and diffusely diseased followed by occlusion (small calibre vessel; figure 1, video 1 ). Right coronary artery (RCA) was ectatic diffusely, and appeared as two balloons (figures 2 and 3, videos 2 and 3 ).

Term ectasia was first used by Bjork. ${ }^{1}$ Markis et $a l^{2}$ provided first prospective evaluation of incidence of coronary artery aneurysm. Coronary ectasia is defined as localised or diffuse dilatation of coronary artery $\geq 1.5$ times adjacent normal vessel segment. ${ }^{3}$ Most common cause of coronary ectasia is atherosclerosis $(=50 \%)$. Coronary angiography is the investigation of choice.

According to Markis classification, our patient had type II ectasia (diffuse in RCA and localised in LAD). The patient was sent for coronary artery bypass graft surgery and is now doing well.

This case shows a classic example of coronary ectasia with typical ballooned coronary in angiogram.

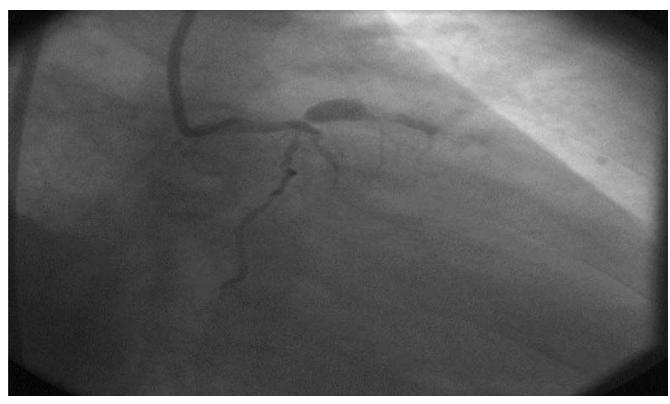

Figure 1 Right anterior oblique caudal view showing ectatic left anterior descending artery followed by total occlusion and diffusely diseased left circumflex coronary artery followed by occlusion.

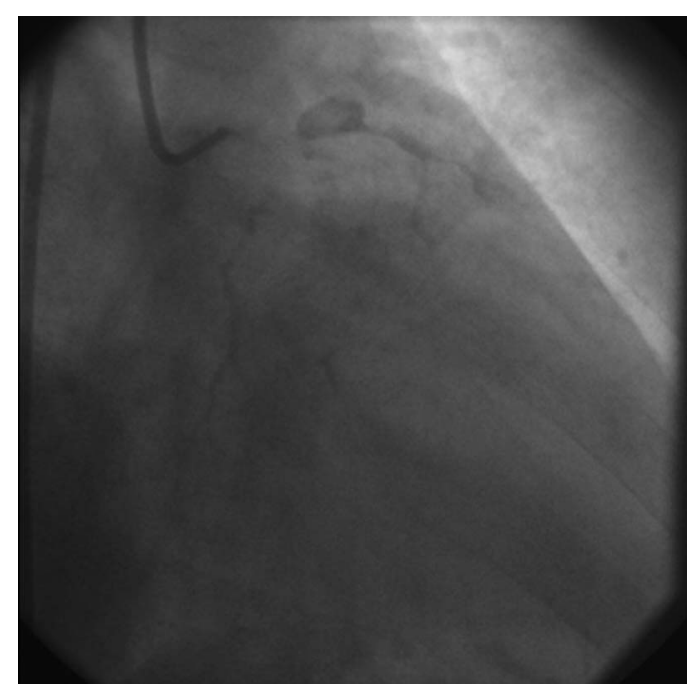

Video 1 Right anterior oblique caudal view showing left anterior descending artery and left circumflex coronary artery.

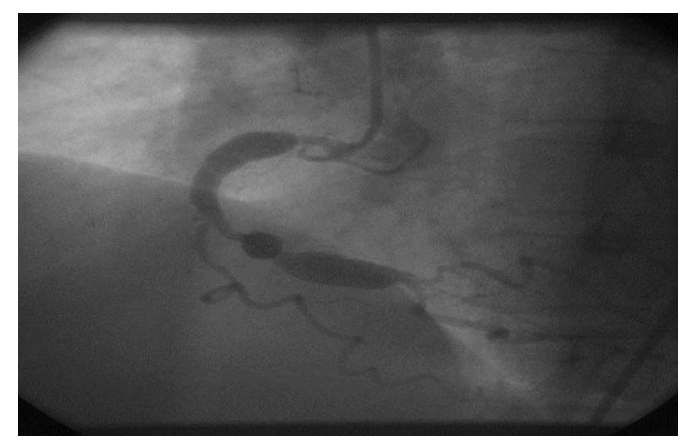

Figure 2 Left anterior oblique view showing ectatic right coronary artery appearing as two balloons.

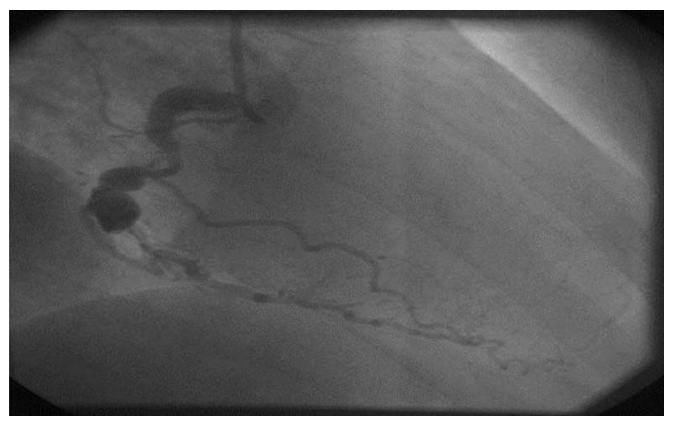

Figure 3 Right anterior oblique view showing ectatic right coronary artery. 


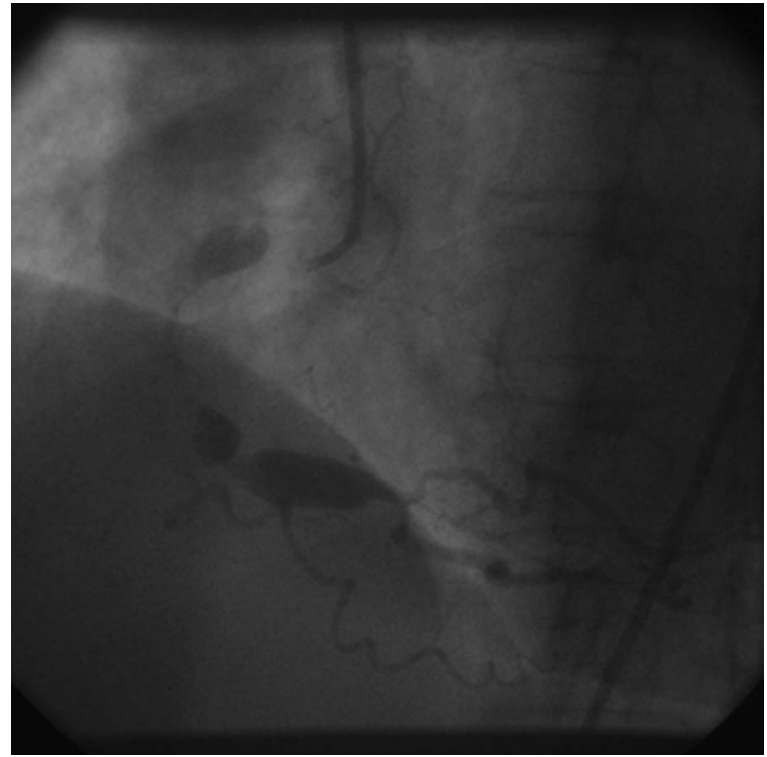

Video 2 Left anterior oblique view showing right coronary artery.

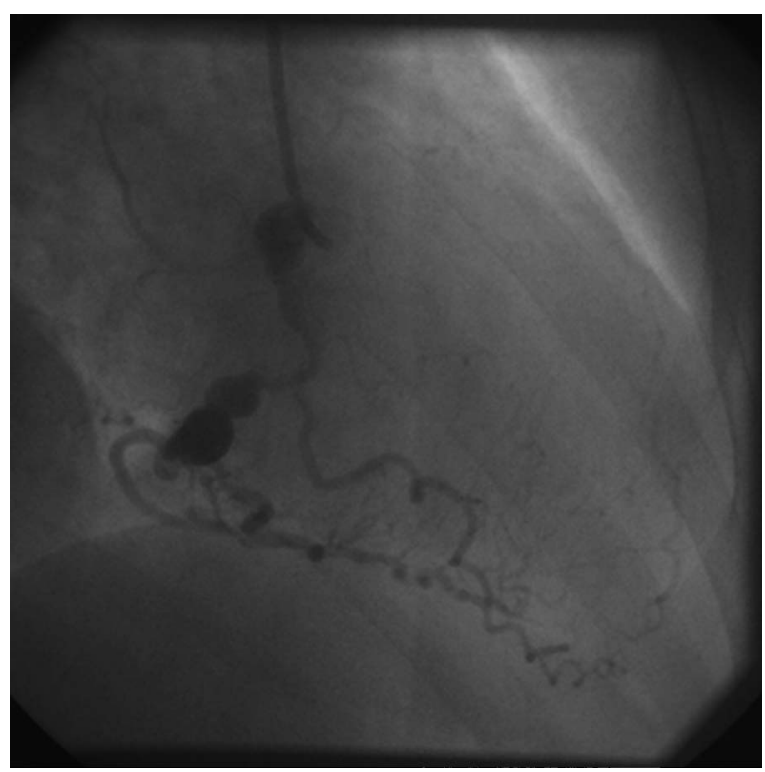

Video 3 Right anterior oblique view showing right coronary artery.

\section{Learning points}

- Coronary ectasia can be found in up to $3-8 \%$ of angiograms.

- Ectatic vessels can present as acute coronary syndrome.

- Most common cause is atherosclerosis.

Contributors HM was involved in the case selection and main manuscript writing. AK was involved in the collection of references. SB edited the article and RR gave the finishing touch to the article.

Competing interests None.

Patient consent Obtained.

Provenance and peer review Not commissioned; externally peer reviewed.

\section{REFERENCES}

1 Bjork L. Ectasia of coronary arteries. Radiol 1966;87:33-4.

2 Markis JE, Joffe CD, Cohn PF, et al. Clinical significance of coronary arterial ectasia. Am J Cardiol 1976;37:217-22.

3 Yilmaz H, Sayar N, Yilmaz M, et al. Coronary artery ectasia: clinical and angiographical evaluation. Turk Kardiyol Dern Ars 2008;36:530-5.

Copyright 2013 BMJ Publishing Group. All rights reserved. For permission to reuse any of this content visit http://group.bmj.com/group/rights-licensing/permissions.

BMJ Case Report Fellows may re-use this article for personal use and teaching without any further permission.

Become a Fellow of BMJ Case Reports today and you can:

- Submit as many cases as you like

- Enjoy fast sympathetic peer review and rapid publication of accepted articles

- Access all the published articles

- Re-use any of the published material for personal use and teaching without further permission

For information on Institutional Fellowships contact consortiasales@bmjgroup.com

Visit casereports.bmj.com for more articles like this and to become a Fellow 